\title{
A key time point for cell growth and magnetosome synthesis of Magnetospirillum gryphiswaldense based on real-time analysis of physiological factors
}

\author{
Jing Yang ${ }^{1,2}$, Shuqi Li $^{1,2}$, Xiuliang Huang ${ }^{1,2}$, Tao Tang ${ }^{1,2}$, Weizhong Jiang ${ }^{3}$, Tongwei Zhang ${ }^{1,4}$ and \\ Ying $L i^{1,2 *}$
}

\author{
Key Laboratory of Agro-biotechnology and Key Laboratory of Soil Microbiology, Ministry of Agriculture, College of Biological Sciences, China Agricultural \\ University, Beijing, China \\ 2 France-China Biomineralization and Nano-structure Laboratory, Beijing, China \\ ${ }^{3}$ College of Water Resources and Civil Engineering, China Agricultural University, Beijing, China \\ ${ }^{4}$ Institute of Geology and Geophysics, Chinese Academy of Sciences, Beijing, China
}

\section{Edited by:}

Wei Lin, Chinese Academy of

Sciences, China

\section{Reviewed by:}

Wei Lin, Chinese Academy of

Sciences, China

Jianbo Sun, Columbia University, USA

\section{*Correspondence:}

Ying Li, State Key Laboratory of Agro-biotechnology and College of

Biological Sciences, China

Agricultural University, No.2,

Yuanmingyuan West Road, Beijing,

100193, China

e-mail:yingli528@vip.sina.com
Pure culture of magnetotactic bacteria with high magnetosome yield has been achieved for only a few strains. The major obstacles involve the nutritional requirements and culture conditions of the cells. To increase cell density and magnetosome production, it is necessary to elucidate the physiological characteristics of a particular strain during cell growth and develop an appropriate artificial control strategy. Large-scale culture of Magnetospirillum gryphiswaldense strain MSR-1 was successfully performed for $48 \mathrm{~h}$ in a 42-L autofermentor, and several key physiological parameters were measured in real time. Maximal values of cell density $\left(\mathrm{OD}_{565}\right)$ (19.4) and cell yield (dry weight) $(4.76 \mathrm{~g} / \mathrm{L}$ ) were attained at $40 \mathrm{~h}$. The key time point for cell growth and magnetosome formation was found to be $18-20 \mathrm{~h}$. At this point, cells entered the log phase of growth, the maximal values of $\mathrm{C}_{\text {mag }}(1.78)$, iron content $(0.47 \%)$, and magnetosome number ( $26 \pm 3$ per cell) were observed, superoxide dismutase (SOD) activity began to decrease more rapidly, ATP content dropped to an extremely low level $(0.17 \mathrm{fmol})$, and reducing power (NADH/NAD ${ }^{+}$ ratio) began to increase very rapidly. Excessive levels of dissolved oxygen ( $\geq 20 \mathrm{ppb}$ ) and lactic acid in the medium caused notable cytotoxic effects after $20 \mathrm{~h}$. Artificial control measures for fermentation must be based on realistic cell physiological conditions. At the key time point $(18-20 \mathrm{~h})$, cell density is high and magnetosomes have matured. The process of magnetosome synthesis involves a high consumption of ATP and reducing power, and the cells require replenishment of nutrients prior to the $18-20 \mathrm{~h}$ time point. Culture conditions that effectively minimize dissolved oxygen accumulation, lactic acid content, and reducing power at this point will enhance magnetosome yield without obvious inhibition of cell growth.

Keywords: Magnetospirillum gryphiswaldense, submerged culture, physiological features, magnetosome synthesis, key time point

\section{INTRODUCTION}

Magnetotactic bacteria (MTB) are a group of aquatic microbes characterized by the ability to orient along magnetic field lines based on the presence of intracellular nano-sized "magnet needles" termed magnetosomes. Magnetosomes are membranebound magnetite $\left(\mathrm{Fe}_{3} \mathrm{O}_{4}\right)$ or greigite $\left(\mathrm{Fe}_{3} \mathrm{~S}_{4}\right)$ crystals that form one or multiple chains within the cell (Jogler and Schüler, 2009; Komeili, 2012). Because of their narrow size distribution (30-120 nm) and uniform morphology, magnetosomes have potential applications in magnetic separation techniques, diagnostics, and analytic detection (Matsunaga et al., 2004; Pollithy et al., 2011). All MTB known to date are difficult to culture because of their strict requirements in terms of nutrition, oxygen, and redox potential (Zhang et al., 2010; Zhu et al., 2010). Most known MTB are obligatory anaerobic, facultative anaerobic, or microaerobic. Therefore, only a small proportion of MTBs can be axenically isolated and cultured, and the obtainable cell densities do not allow the purification of sufficient numbers of magnetosomes for industrial applications (Jogler and Schüler, 2009). Improved methods are needed to increase MTB cell density and magnetosome yield at a reasonable cost.

Magnetospirillum gryphiswaldense MSR-1 is an MTB strain that has been the subject of considerable genetic research and can be cultured at high densities relative to other MTB (Jogler and Schüler, 2009). In a 2008 study, we achieved MSR-1 fermentation cell density $\left(\mathrm{OD}_{565}\right) 7.24$, cell yield $2.17 \mathrm{~g} / \mathrm{L}$, and magnetosome yield $41.7 \mathrm{mg} / \mathrm{L}$ (Sun et al., 2008). In 2010, we achieved cell density 12.0 and magnetosome yield $83.23 \mathrm{mg} / \mathrm{L}$ (Liu et al., 2010). In 2011, using an improved strategy for high-density culture of MSR-1 and large-scale magnetosome production through semicontinuous culture and reduction of osmotic factors that tend to inhibit cell growth, we achieved cell yield 9.16 g/L and 
magnetosome yield $356.52 \mathrm{mg} / \mathrm{L}$ (Zhang et al., 2011). In each of these studies, we focused on optimization of culture medium, adjustment of oxygen level and $\mathrm{pH}$, and addition of nutrients, but did not carefully monitor cell physiological indicators. Increased knowledge of the physiological characteristics of the dynamic cell growth process will be helpful. i.e., better understanding of the physiology and growth principles of MTBs will allow us to reduce the effects of specific physiological inhibitors and further increase magnetosome yield. By analyzing cells cultured under physiological conditions, we can elucidate realistic principles of MSR-1 growth and develop improved stability control strategies.

We report here new comprehensive findings on MSR-1 culture and cell physiological features during submerged culture in a 42 -L autofermentor. In preliminary experiments, we evaluated a variety of physiological parameters, including growth curves, magnetism $\left[\mathrm{C}_{\mathrm{mag}}\right.$ value, ratio of maximal and minimal scattering intensities (Schüler et al., 1995)], dissolved oxygen $\left(\mathrm{dO}_{2}\right)$ and lactic acid (LA) levels in medium, iron content, ATP content, reducing power, and superoxide dismutase (SOD) activity in cells. Striking changes in most of these parameters were observed between hours 18-20 of culture, indicating a key time point for MSR-1 cell growth and magnetosome synthesis. The decreased levels of $\mathrm{dO}_{2}$, LA, and reducing power occurring at this key time point can be exploited for the improvement magnetosome yield without obvious inhibition of cell growth. This study is the first to utilize physiological parameters for the evaluation of MSR-1phenotype during fermentation. Our findings may be applicable to the culture of other MTB and microaerobic bacteria.

\section{MATERIALS AND METHODS SUBMERGED CULTURE OF CELLS IN A 42-L AUTOFERMENTOR}

M. gryphiswaldense strain MSR-1 (DSM6361) was purchased from Deutsche Sammlung von Mikroorganismen und Zellkulturen (Brunswick, Germany). Seed culture was performed as described previously (Liu et al., 2010). The 42-L fermentor was filled with $30 \mathrm{~L}$ of medium containing $1.5 \mathrm{~g}$ sodium thioglycolate, $6 \mathrm{~g}$ magnesium sulfate heptahydrate, $15 \mathrm{~g}$ yeast extract, $6 \mathrm{~g}$ peptone, and $15 \mathrm{~mL}$ Wolfe's mineral solution. Feed medium contained $4.2 \mathrm{~g}$ ferric citrate, $129 \mathrm{~g}$ sodium lactate, $52.6 \mathrm{~g} \mathrm{LA}$, and $54.9 \mathrm{~g}$ ammonium chloride in a volume of $700 \mathrm{~mL}$. MSR-1 cells were continuously cultured in the fermentor for $48 \mathrm{~h}$, at which point the $\mathrm{OD}_{565}$ value began to decrease following a long-term rise. The temperature and $\mathrm{pH}$ were controlled to $30^{\circ} \mathrm{C}$ and 6.8 , respectively, during culture. The $\mathrm{pH}$ was adjusted via the feed medium. The $\mathrm{dO}_{2}$ concentration was recorded using two probes that had different purposes. One probe was used for relative measurement (percent $\%$ as unit of data) and had lower accuracy. The other probe was used for absolute measurement (ppb as unit of data) and had higher accuracy. Calibration prior to measurements was required for the former probe but not for the latter. Before inoculation, we maintained an initial stirring rate $(120 \mathrm{rpm})$ and airflow rate $(0.94 \mathrm{~L} / \mathrm{min})$ for $2 \mathrm{~h}$ to ensure that oxygen was at saturation level in the medium. We then calibrated the $\mathrm{dO}_{2}$ as closely as possible to $100 \%$ (there were occasional minor fluctuations). The various study parameters were recorded after inoculation as functions of time (Table 1).

Samples were taken every few hours for further analysis. After sampling, cell density $\left(\mathrm{OD}_{565}\right)$ and magnetism $\left(\mathrm{C}_{\mathrm{mag}}\right)$ were measured immediately using the same spectrophotometer at wavelength $565 \mathrm{~nm}$ as described by Schüler et al. (1995). A 2$\mathrm{mL}$ culture sample was centrifuged, and the LA concentration of the supernatant was measured immediately using a SBA-40C Biosensor analyzer (Institute of Biology, Shandong Academy of Sciences, China). Cells (in a defined volume) were washed twice with $50 \mathrm{mM}$ Tris buffer $\left(\mathrm{pH} \mathrm{7.0)}\right.$ ) and centrifuged at $4^{\circ} \mathrm{C}$, and the cell pellets were stored at $-80^{\circ} \mathrm{C}$. Culture samples were suspended in an appropriate volume of sterile distilled water for subsequent measurements.

\section{IRON CONTENT}

Another 2-mL culture sample was centrifuged in a $1.5-\mathrm{mL}$ tube, and the pellet was dried at $60^{\circ} \mathrm{C}$ until it reached a constant weight. Iron content was measured by Inductively Coupled Plasma Optical Emission Spectrometry (ICP-OES; model Optima 5300DV, Perkin Elmer, Waltham MA, USA). The percentage of iron in cells was calculated as the iron content divided by the dry weight.

\section{ATP CONTENT}

Another 2-mL culture sample was added with 10\% trichloroacetic acid solution $(1: 1, \mathrm{v} / \mathrm{v})$, incubated on ice for $10 \mathrm{~min}$, and

Table 1 | Adjustment of dissolved oxygen $\left(\mathrm{dO}_{2}\right)$ and corresponding values of $O_{565}$ and $C_{\text {mag }}$ during submerged culture of MSR-1 cells.

\begin{tabular}{|c|c|c|c|c|c|c|}
\hline \multirow{2}{*}{$\begin{array}{l}\text { Time } \\
\text { (h) }\end{array}$} & \multirow{2}{*}{$\begin{array}{l}\text { Stirring } \\
\text { rate (rpm) }\end{array}$} & \multirow{2}{*}{$\begin{array}{l}\text { Airflow rate } \\
\text { (L/min) }\end{array}$} & \multicolumn{2}{|c|}{$\mathrm{dO}_{2}$} & \multirow[t]{2}{*}{$O D_{565}$} & \multirow[t]{2}{*}{$C_{\text {mag }}$} \\
\hline & & & $(\%)$ & (ppb) & & \\
\hline 0 & 120 & 0.94 & 102.70 & 2451 & 0.1 & 0.74 \\
\hline 8 & 120 & 0.95 & 0.00 & 12 & 0.3 & 0.24 \\
\hline 10 & 140 & 1.45 & 0.00 & 4 & 0.4 & 0.80 \\
\hline 12 & 160 & 1.95 & 0.00 & 4 & 0.7 & 1.39 \\
\hline 14 & 180 & 1.97 & 0.00 & 3 & 1.1 & 1.38 \\
\hline 16 & 180 & 1.95 & 0.00 & 2 & 1.5 & 1.65 \\
\hline 18 & 200 & 1.95 & 0.00 & 3 & 1.7 & 1.52 \\
\hline 20 & 230 & 2.95 & 0.00 & 6 & 2.1 & 1.78 \\
\hline 22 & 250 & 3.98 & 0.00 & 4 & 3.2 & 1.65 \\
\hline 24 & 270 & 3.96 & 0.00 & 17 & 4.8 & 1.71 \\
\hline 26 & 280 & 3.99 & 0.00 & 35 & 6.3 & 1.38 \\
\hline 28 & 290 & 3.98 & 0.00 & 9 & 8.3 & 1.50 \\
\hline 30 & 300 & 3.97 & 0.00 & 215 & 10.8 & 1.54 \\
\hline 32 & 300 & 1.97 & 0.00 & 186 & 13.7 & 1.68 \\
\hline 34 & 300 & 1.95 & 0.00 & 204 & 14.6 & 1.41 \\
\hline 36 & 300 & 1.95 & 12.40 & 661 & 16.8 & 1.43 \\
\hline 38 & 300 & 1.95 & 21.60 & 962 & 18.1 & 1.20 \\
\hline 40 & 300 & 1.95 & 29.80 & 1247 & 19.4 & 1.12 \\
\hline
\end{tabular}

$\mathrm{dO}_{2}$ was measured using two probes with differing accuracies (see Materials and Methods). To maintain $\mathrm{dO}_{2}$ at the level suitable for magnetosome synthesis (0.0\%), the stirring rate was changed at $10,12,14,18,20,22,24,26,28$, and $30 \mathrm{~h}$, and the airflow rate was changed at 10,12,20,22, and $32 \mathrm{~h}$. 
centrifuged for $5 \mathrm{~min}$ at $4^{\circ} \mathrm{C}$. The ATP content of the supernatant was measured using an AF-100 ATP analyzer (DKK-TOA Corp., Tokyo, Japan). The ATP content of the sample was calculated as total ATP content / volume of sample/OD 565 of sample.

\section{REDUCING POWER}

Reducing power was measured by a modification of the method of Perez et al. (2008). For NADH measurement, a 1-mL sample was incubated with $50 \mu \mathrm{L} \mathrm{KOH}(0.4 \mathrm{~mol} / \mathrm{L}, \mathrm{pH} 12.3)$ for $10 \mathrm{~min}$ at $30^{\circ} \mathrm{C}$, centrifuged $(12,000 \mathrm{rpm})$ for $10 \mathrm{~min}$ at $4^{\circ} \mathrm{C}$, and the supernatant was assayed. For $\mathrm{NAD}^{+}$measurement, a $1-\mathrm{mL}$ sample was incubated with $125 \mu \mathrm{L} \mathrm{HCl}(0.4 \mathrm{~mol} / \mathrm{L}, \mathrm{pH} 1.3)$ for $10 \mathrm{~min}$ at $5^{\circ} \mathrm{C}$, centrifuged $(12,000 \mathrm{rpm})$ for $10 \mathrm{~min}$ at $4^{\circ} \mathrm{C}$, and the supernatant was assayed. The reducing power was calculated as the ratio of $\mathrm{NADH}$ to $\mathrm{NAD}^{+}$.

\section{TRANSMISSION ELECTRON MICROSCOPY (TEM)}

A culture sample was placed on a copper grid, washed twice with distilled water, dried, and observed with a transmission electron microscope (model JEM1230; JEOL, Tokyo, Japan).

\section{SUPEROXIDE DISMUTASE ACTIVITY}

Cells were lysed by ultrasonication (ice bath, $50 \mathrm{~W}, 200$ times, $50 \%$ duty cycle). Cell debris was removed by centrifugation at $4^{\circ} \mathrm{C}$ to yield a supernatant (used as crude enzyme extract), and the protein content (mg) was measured by Coomassie Brilliant Blue assay (Chial et al., 1993). The total SOD activity was measured using a SOD assay kit (Jiancheng Corp., Nanjing, China). The SOD activity of a sample was calculated as the total SOD activity divided by protein content.

\section{RESULTS \\ PRECISE CONTROL OF DISSOLVED OXYGEN CONCENTRATION ENSURES OPTIMAL CONDITIONS FOR MAGNETOSOME FORMATION}

We performed several preliminary experiments to obtain stable results based on our past experience. Although there were slight differences in the data from different batches, the overall trends for cell growth rate and magnetosome yield were consistent (see Figures 1A, S1). The results from a representative experiment are shown in Figure 1 as an example. As showed in Figure 1, cells grew slowly $\left(\mathrm{OD}_{565} \leq 2.0\right)$ until hour 20 . Thereafter, cell growth entered the log phase. Maximal values of $\mathrm{OD}_{565}$ (19.4) (Figure 1A) and cell yield (dry weight) $(4.76 \mathrm{~g} / \mathrm{L})$ were observed at hour 40. In MSR-1 culture, high $\mathrm{dO}_{2}$ levels (>1\%) promote cell growth but inhibit magnetosome formation (Heyen and Schüler, 2003; Liu et al., 2010). To balance these conflicting effects, we set the initial (hour 0) stirring rate to $120 \mathrm{rpm}$, the airflow rate to $0.94 \mathrm{~L} / \mathrm{min}$ and the saturated $\mathrm{dO}_{2}$ under these conditions to $100 \%$ (showed $102.7 \%$ after setting), based on the results of our previous study (Liu et al., 2010). After inoculation, the $\mathrm{dO}_{2}$ level decreased rapidly to $0.0 \%$ at $8 \mathrm{~h}$ (Table 1). During this period, cell density $\left(\mathrm{OD}_{565}\right)$ increased 3fold (from 0.1 at $0 \mathrm{~h}$ to 0.3 at $8 \mathrm{~h}$ ), indicating a high oxygen requirement during the early stage of cell growth. To maintain a suitable $\mathrm{dO}_{2}(0.0 \%)$ for magnetosome formation, we subsequently altered the stirring rate at 2 -h intervals between 10 and $30 \mathrm{~h}$ and altered the airflow rate at $10,12,20,22$, and $32 \mathrm{~h}$
(Table 1). To precisely control $\mathrm{dO}_{2}$ concentration, we used two probes with differing accuracies as described in Materials and Methods, one for relative $\mathrm{dO}_{2}$ measurement (percent \%), the other for absolute measurement (ppb). This approach allowed us to accurately detect even tiny changes of $\mathrm{dO}_{2}$, particularly at extremely low concentrations. From 28 to $34 \mathrm{~h}$, the absolute $\mathrm{dO}_{2}$ level gradually increased nearly 23-fold, from 9 to $204 \mathrm{ppb}$, while the probe used for relative measurement continuously showed a value below the limit of detection $(0.0 \%)$, which may have caused a delay in adjusting the stirring rate and airflow rate in the fermentor (Table 1). A high $\mathrm{dO}_{2}$ concentration affected magnetosome formation. From 8 to $24 \mathrm{~h}$, the absolute $\mathrm{dO}_{2}$ concentration remained $<20 \mathrm{ppb}$, while the $\mathrm{C}_{\text {mag }}$ value increased from 0.24 at $8 \mathrm{~h}$ to 1.78 at $20 \mathrm{~h}$ and remained high until $24 \mathrm{~h}$ (Figure 1B). $\mathrm{dO}_{2}$ increased gradually from $17 \mathrm{ppb}$ at $24 \mathrm{~h}$ to $1247 \mathrm{ppb}$ at $40 \mathrm{~h}$, while $\mathrm{C}_{\text {mag }}$ decreased from 1.71 at $24 \mathrm{~h}$ to 1.12 at $40 \mathrm{~h}$. Taken together, these findings indicate that the optimal concentration of absolute $\mathrm{dO}_{2}$ for magnetosome production is $<20$ ppb.

\section{LACTIC ACID CONCENTRATION REFLECTS GROWTH STATE}

The LA feed medium contained LA, sodium lactate, ferric citrate, and ammonium chloride (see Materials and Methods). The LA in this medium was utilized both as a carbon source and a $\mathrm{pH}$ regulator. The supply of feed medium was auto-controlled via a computer to maintain a $\mathrm{pH}$ value of 6.8 throughout cell culture. The LA concentration in medium at each time point was recorded using a Biosensor analyzer and used as an indicator of the cell growth state. The LA concentration decreased rapidly from $0.26 \mathrm{~g} / \mathrm{L}$ at $12 \mathrm{~h}$ to $0.01 \mathrm{~g} / \mathrm{L}$ at $26 \mathrm{~h}$, corresponding to the $\log$ phase of growth curve and reflecting the high cellular demand for LA as a source of carbon and energy for growth (Figure 1C). The LA concentration then increased from $0.01 \mathrm{~g} / \mathrm{L}$ at $26 \mathrm{~h}$ to $0.16 \mathrm{~g} / \mathrm{L}$ at $40 \mathrm{~h}$. Excessive LA was present during this period and was associated with frequent $\mathrm{pH}$ fluctuations and rapid cellular metabolism (Figure 1C).

\section{THE PERIOD 18-20 H IS A KEY TIME POINT FOR IRON METABOLISM AND MAGNETOSOME PRODUCTION}

$\mathrm{C}_{\text {mag }}$ can be a useful parameter for estimating the magnetosome content of cells (Schüler et al., 1995), but it is based on an indirect method. A more direct method of measurement is based on TEM and the iron content of cells. The iron content in MTB can be 100fold (or more) higher than in E. coli (Blakemore et al., 1979) and is concentrated primarily in magnetosomes (Kasama et al., 2006). We measured iron content by ICP-OES as described in Materials and Methods. $\mathrm{C}_{\text {mag }}$ and iron content both increased gradually from 8 to $20 \mathrm{~h}$, reached maximal values $(1.78$ and $0.47 \%$ ) at $20 \mathrm{~h}$, and then decreased (to 1.12 and $0.20 \%$, respectively) at $40 \mathrm{~h}$ (Figure 1D). TEM showed that the average number of magnetosomes per cell increased from 12 to 24 during the initial phase $(0-20 \mathrm{~h})$ and that magnetosome chains were not integrated at $12 \mathrm{~h}$ (Figures 2, S2 and Table 2). From 20 to $40 \mathrm{~h}$, the average magnetosome number remained essentially constant $(26 \pm 3)$, and the chains were gradually integrated and matured (Figures 2, S2). We concluded that $20 \mathrm{~h}$ is an important transitional time point for magnetosome production. In view of the rapid decrease of 

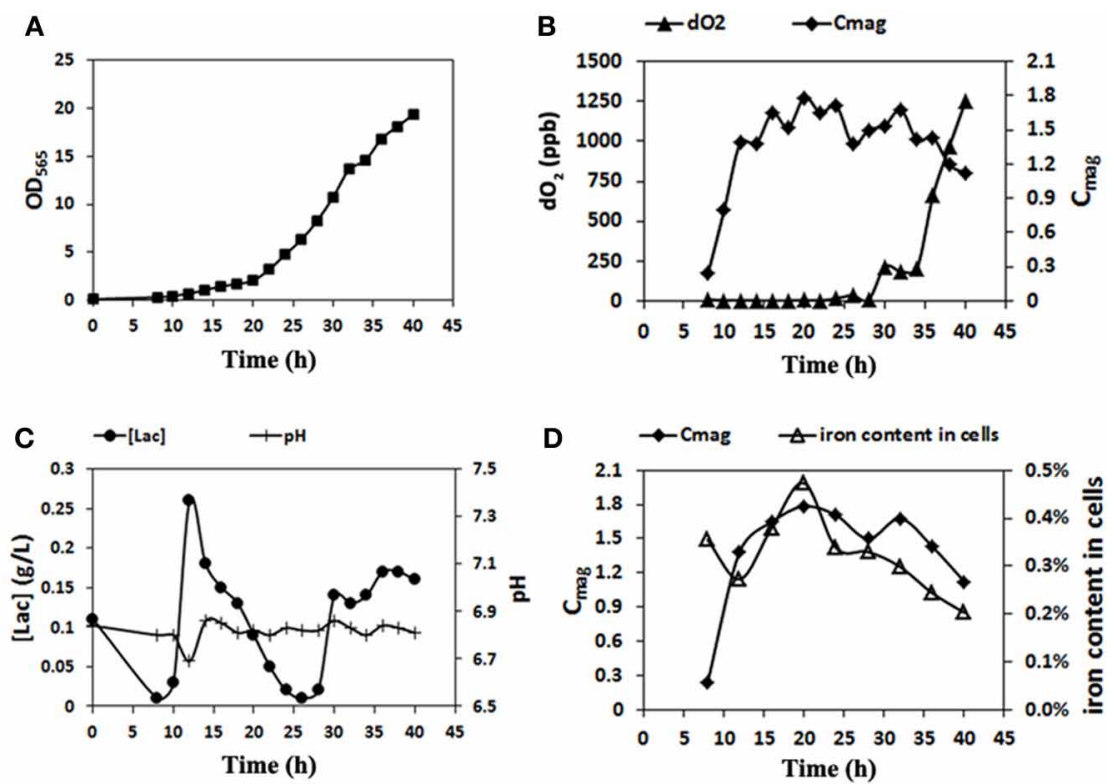

E

$\mathbf{F}$
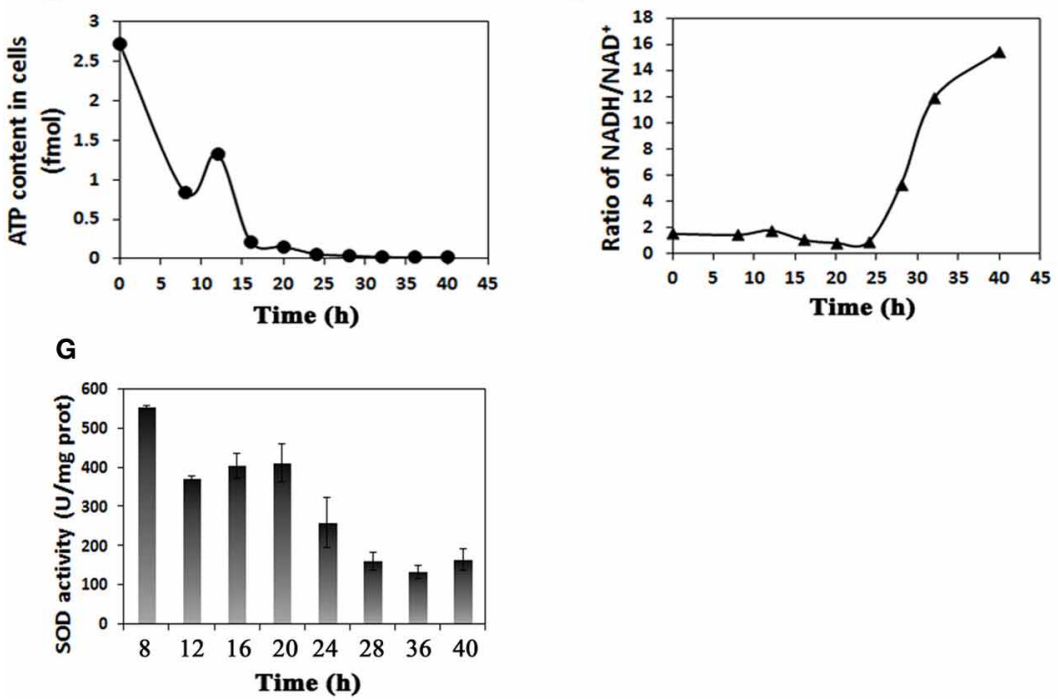

FIGURE 1 | Real-time physiological parameters of MSR-1 cells in submerged cultured in a $\mathbf{4 2} \mathrm{L}$ autofermentor. (A) Cell growth curve $\left(O D_{565}\right)$. Cells entered the log growth phase at $20 \mathrm{~h}$ and reached maximal $\mathrm{OD}$ at $40 \mathrm{~h}$. (B) Comparison of dissolved oxygen $\left(\mathrm{dO}_{2}\right)$ concentration and $\mathrm{C}_{\text {mag }}$ revealed that the optimal absolute $\mathrm{dO}_{2}$ concentration for

magnetosome production is $<20 \mathrm{ppb}$. (C) Lactic acid concentration ([lac])

and $\mathrm{pH}$ value were under coordinated control. (D) The level of iron content was closely related to that of $\mathrm{C}_{\text {mag }}$. (E) Cell ATP content decreased rapidly from 0 to $20 \mathrm{~h}$ and much more gradually thereafter. (F) The NADH/NAD ${ }^{+}$ ratio was low from 0 to $25 \mathrm{~h}$ and increased rapidly thereafter. (G) SOD activity assays at sampling times from 8 to $40 \mathrm{~h}$. SOD activity was notably reduced after $20 \mathrm{~h}$.

LA content in medium around this time (Figure 1C), it is clearly important to provide sufficient nutritional supplements prior to $20 \mathrm{~h}$ to ensure the rapid growth of new cells.

\section{MAGNETOSOME SYNTHESIS CONSUMES A LARGE AMOUNT OF ATP AND ACCUMULATES REDUCING POWER}

The formation of magnetosomes in MTB is presumed to consume a large amount of energy. The availability of ATP as an energy source has been shown to be required for iron uptake in MTB (Nakamura et al., 1995; Schüler, 1999). We used an ATP analyzer to measure the ATP content of cells. From 0 to $20 \mathrm{~h}$, the period of magnetosome synthesis, energy (i.e., ATP content) in cells decreased rapidly from 2.73 to 0.17 fmol. From 20 to $40 \mathrm{~h}$, the ATP content continued to decrease from $0.17 \mathrm{fmol}$ to near zero $(0.02 \mathrm{fmol})$; however, the rate of decrease was lower than that from $0 \mathrm{~h}$ to $20 \mathrm{~h}$ (Figure 1E).

$\mathrm{NADH}$ plays an important role in ATP generation in cells and provides a proton gradient across the inner mitochondrial membrane for ATP production by ATP synthetase (Bonora et al., 2012). We used a modified enzyme reduction 


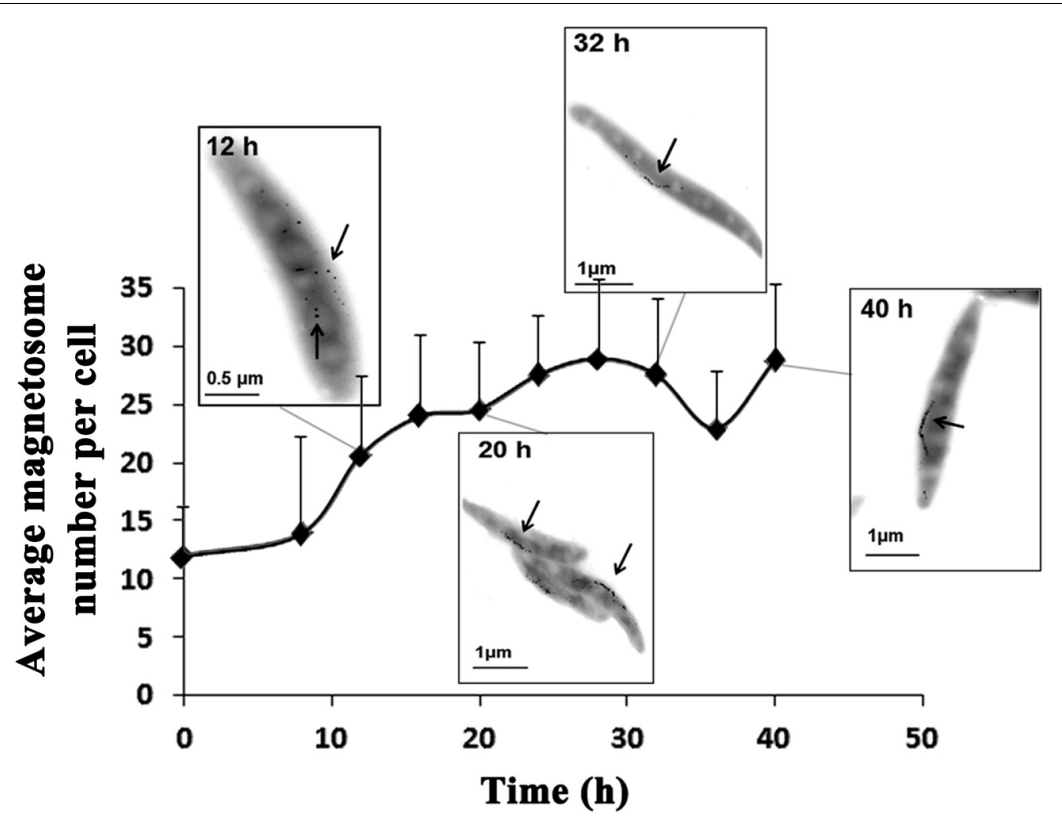

FIGURE 2 | Magnetosome number increased as a function of time. Typical TEM photos taken at 12, 20, 32, and 40 h are shown. At $8 \mathrm{~h}$, magnetosomes were scattered. From 20 to 40 h, magnetosome chains became completed and mature. Magnetosomes are indicated by arrows.

Table 2 | Statistical processing of magnetosome number per cell at different time points.

\begin{tabular}{|c|c|c|c|c|c|c|c|c|c|c|c|}
\hline & \multicolumn{11}{|c|}{ Sampling time points } \\
\hline \multirow{6}{*}{$\begin{array}{l}\text { Percentage of magnetosome } \\
\text { number per cell }(\%)\end{array}$} & $6-10$ & 44.4 & 42.9 & 10.0 & 0.0 & 3.4 & 0.0 & 0.0 & 0.0 & 0.0 & 0.0 \\
\hline & $11-15$ & 27.8 & 23.8 & 10.0 & 8.7 & 3.4 & 0.0 & 0.0 & 0.0 & 4.8 & 0.0 \\
\hline & $16-20$ & 16.7 & 23.8 & 25.0 & 26.1 & 24.1 & 4.3 & 10.0 & 13.0 & 38.1 & 12.5 \\
\hline & $26-30$ & 0.0 & 0.0 & 25.0 & 21.7 & 31.0 & 30.4 & 40.0 & 13.0 & 19.0 & 16.7 \\
\hline & $31-35$ & 0.0 & 0.0 & 5.0 & 13.0 & 13.8 & 21.7 & 20.0 & 43.5 & 14.3 & 37.5 \\
\hline & $36-40$ & 0.0 & 0.0 & 0.0 & 4.3 & 0.0 & 8.7 & 10.0 & 4.3 & 0.0 & 12.5 \\
\hline $\mathrm{AVE}^{*}$ & & 11.7 & 14.3 & 20.9 & 23.9 & 24.5 & 28.1 & 28.6 & 28.1 & 22.7 & 28.0 \\
\hline$S D^{* *}$ & & 4.3 & 8.7 & 7.0 & 6.4 & 5.5 & 5.3 & 6.9 & 6.3 & 5.3 & 6.7 \\
\hline
\end{tabular}

*Average magnetosome number per cell.

** Standard deviation.

method to measure reducing power (as the ratio NADH/NAD ${ }^{+}$) (Perez et al., 2008). In contrast to the trend for ATP, the $\mathrm{NADH} / \mathrm{NAD}^{+}$ratio remained low $(\leq 2)$ and fluctuated slightly during the first $20 \mathrm{~h}$ (Figure 1F). Thereafter, as the cells entered the $\log$ phase of growth and the magnetosomes matured, the $\mathrm{NADH} / \mathrm{NAD}^{+}$ratio increased rapidly to 15 at $40 \mathrm{~h}$. These findings indicate that the process of magnetosome synthesis consumes a large amount of ATP and accumulates reducing power.

\section{SUPEROXIDE DISMUTASE ACTIVITY DECREASES RAPIDLY AFTER $20 \mathrm{~h}$}

SOD in microbes helps remove the superoxide anion radical $\left(\mathrm{O}_{2}^{-}\right)$and hydrogen peroxide $\left(\mathrm{H}_{2} \mathrm{O}_{2}\right)$, which have destructive effects on cell macromolecules (Cabiscol et al., 2000). In MTB, SOD also reduces oxidative stress during magnetosome formation. We used a SOD assay kit to monitor SOD activity in cells. The activity declined gradually from $555 \mathrm{U} / \mathrm{mg}$ at $8 \mathrm{~h}$ to $410 \mathrm{U} / \mathrm{mg}$ at $20 \mathrm{~h}$ and then rapidly to $164 \mathrm{U} / \mathrm{mg}$ at $40 \mathrm{~h}$ (Figure 1G).

\section{DISCUSSION}

The development of improved methods for high-yield magnetosome production has been a major goal of MTB research for over a decade. Progress in this area has been achieved primarily through optimization of $\mathrm{pH}$, temperature, redox potential, $\mathrm{dO}_{2}$ level, and growth medium and feed medium composition (Heyen 
and Schüler, 2003; Sun et al., 2008; Liu et al., 2010; Zhang et al., 2011). Our knowledge of the physiological characteristics of MTB during the dynamic process of cell growth remains fragmentary (Ban et al., 2010). Even the reason why the growth of several MTBs is promoted by trace quantities of peptone remains unclear (Heyen and Schüler, 2003; Zhu et al., 2010). We recently observed that sodium chloride acts as a physiological inhibitor of MSR1 growth (Zhang et al., 2011). Further studies of physiological factors in MTB are needed.

We achieved successful large-scale culture of MSR-1 in a 42-L fermentor during $48 \mathrm{~h}$ in the present study. Maximal cell density and cell yield were $19.4\left(\mathrm{OD}_{565}\right)$ and $4.76 \mathrm{~g} / \mathrm{L}$ (dry weight), respectively. Higher values were attained in one of our previous studies (Liu et al., 2010). We measured the dynamic values of 9 key physiological parameters: growth curve, magnetism $\left(\mathrm{C}_{\mathrm{mag}}\right), \mathrm{dO}_{2}$ and LA content in medium, iron content, magnetosome number, ATP content, reducing power, and SOD activity in cells. The period from 18 to $20 \mathrm{~h}$ was identified as a key time point for cell growth and magnetosome formation. During this period, cell growth entered its log phase, maximal cellular values of $\mathrm{C}_{\mathrm{mag}}(1.78)$, iron content $(0.47 \%)$, and magnetosome number $(26 \pm 3)$ were reached, SOD activity began to decline more rapidly, ATP content dropped to near-zero, and reducing power $\left(\mathrm{NADH} / \mathrm{NAD}^{+}\right.$ratio) increased rapidly. To precisely control $\mathrm{dO}_{2}$, we performed measurements using two probes with differing accuracies. The optimal $\mathrm{dO}_{2}$ concentrations for magnetosome production were $0.0 \%$ (relative) and $<20 \mathrm{ppb}$ (absolute).

LA in feed medium is used as both a carbon source and $\mathrm{pH}$ regulator. From 12 to $26 \mathrm{~h}$, the LA concentration decreased rapidly, corresponding to the log phase of growth and reflecting the high cellular demand for LA as a source of carbon and energy for growth. We therefore recommend that pure sodium lactate be added intermittently to the feed medium during this period to meet the requirements of the cells. From 26 to $40 \mathrm{~h}$, the LA concentration increased greatly, resulting in excessive LA levels associated with frequent $\mathrm{pH}$ fluctuations and rapid cellular metabolism. Excessive levels of organic acids such as LA have been shown to inhibit cell growth (Pieterse et al., 2005); this effect may explain the gradual reduction of growth rate we observed. As an alternative to the use of LA, we can adjust the $\mathrm{pH}$ using other compounds (e.g., carbon dioxide) or by adding feed medium manually at later stages.

ATP is the major energy source in cells and is required for physiological processes such as cell metabolism, signal transduction, and molecular transportation. In MTB, ATP is also involved in iron uptake (Nakamura et al., 1995; Schüler, 1999)and inducing the polymerization of MamK (Mitraki et al., 2012), an actinlike protein involved in the alignment of magnetosome chains (Scheffel et al., 2005). Our findings demonstrate that magnetosome synthesis in MTB consumes large amounts of ATP. NADH plays an important role in generating ATP and provides a proton gradient across the inner mitochondrial membrane for ATP production by ATP synthetase (Bonora et al., 2012). In contrast to the usual trend of ATP change, NADH was accumulated during the fermentation process. We found previously that reducing power is significantly increased during magnetosome synthesis and that excessive reducing power suppresses magnetosome synthesis and cell growth in later periods (unpubl. data). A high $\mathrm{NADH} / \mathrm{NAD}^{+}$ratio indicates that little NADH is being used to supply protons, resulting in a low cellular ATP content. In MTB, excessive reducing power is consumed through polyhydroxybutyrate (PHB) synthesis and hydrogen release (Ban et al., 2010). This process may account in part for the fact that MTB contain many PHB granules (Schultheiss et al., 2005; Komeili, 2006). When PHB synthase gene was knocked out in MSR-1, the amount of magnetosome increased nearly $30 \%$ compared with wild-type strain (Liu et al., 2008). So, it seems that an energy competition exists between the $\mathrm{PHB}$ and magnetosome synthesis process.

$\mathrm{H}_{2} \mathrm{O}_{2}$ can form a hydroxyl radical (HO.) when it receives an electron from ferrous iron. HO. is the only reactive oxygen species that can directly damage most biomolecules (Imlay, 2003). In the present study, magnetosomes reached their maximal number at $20 \mathrm{~h}$. At this point, reductions were observed for the intracellular iron content (Figure 1D) and the amount of SOD used to remove reactive oxygen species (Figure 1G). This could be explained as, in the late log phase, when $\mathrm{dO}_{2}$ and nutrients were enough, magnetosome formation and maturation maybe cannot catch up the cell dividing rate, resulting in diluted magnetosomes in cells, which was indicated by the $\mathrm{C}_{\mathrm{mag}}$ trend (Figure 1D). Therefore, the reduced SOD activity may be caused similarly from diluted reactive oxygen species. Recent studies have shown that magnetosomes and artificial magnetic nanoparticles are able to scavenge reactive oxygen species (Gao et al., 2007; Guo et al., 2012). This ability may account in part for the observed decrease in SOD activity.

\section{CONCLUSION}

Artificial manipulation of fermentation processes for maximizing yield must be based on realistic cell physiological conditions. We found that $18-20 \mathrm{~h}$ is a key time point for M. gryphiswaldense MSR-1 cell growth and magnetosome synthesis. At this point, cell density is high, magnetosomes have matured, and cells require replenishment of nutrients. Culture conditions that effectively minimize $\mathrm{dO}_{2}$ accumulation, LA content, and reducing power at this point will promote magnetosome yield without obvious inhibition of cell growth. Artificial culture of MTB requires precise control of $\mathrm{dO}_{2}$ at low concentrations $(\leq 20 \mathrm{ppb})$ that are suitable for magnetosome synthesis. Future analytical transcriptome studies involving the forced expression of MSR-1 genes that are involved in the metabolism of ATP, NADH, oxygen and iron will help us elucidate the optimal conditions for MTB culture.

\section{ACKNOWLEDGMENTS}

This study was supported by the National Natural Science Foundation of China (Grants No. 31270093 and J1103520) and the Undergraduate Innovation Program of China Agricultural University (Grant No. 2010-BKS-16). The authors thank Dr. Wei Jiang for technical help with submerged culture, Dr. Jingwen Lu for help with determination of cell ATP content, and Dr. S. Anderson for English editing of the manuscript. 


\section{SUPPLEMENTARY MATERIAL}

The Supplementary Material for this article can be found online at: http://www.frontiersin.org/Aquatic_Microbiology/ 10.3389/fmicb.2013.00210/abstract

FIGURE S1 | A set of representative preliminary fermention data: growth and $\mathbf{C}_{\mathrm{mag}}$ curves. Cell growth enters the log phase at $20 \mathrm{~h}$, with a maximum $\mathrm{OD}_{565}$ value at $36 \mathrm{~h}$. $\mathrm{C}_{\text {mag }}$ increased gradually from 8 to $20 \mathrm{~h}$, reached maximal values at $20 \mathrm{~h}$,

\section{REFERENCES}

Ban, J., Jiang, W., Li, Y., Zhang, Y., and Li, J. (2010). Functional analysis of hydrogenases and their effects on cell growth and magnetosome synthesis in Magnetospirillum gryphiswaldense. Chin. Sci. Bull. 55, 1271-1277. doi: 10.1007/s11434-009-0744-8

Blakemore, R. P., Maratea, D., and Wolfe, R. S. (1979). Isolation and pure culture of a freshwater magnetic spirillum in chemically defined medium. J. Bacteriol. 140, 720-729.

Bonora, M., Patergnani, S., Rimessi, A., De Marchi, E., Suski, J. M., Bononi, A., et al. (2012). ATP synthesis and storage. Purinergic Signal. 8, 343-357. doi: 10.1007/s11302012-9305-8

Cabiscol, E., Tamarit, J., and Ros, J. (2000). Oxidative stress in bacteria and protein damage by reactive oxygen species. Int. Microbiol. 3, 3-8.

Chial, H. J., Thompson, H. B., and Splittgerber, A. G. (1993). A spectral study of the charge forms of Coomassie blue G. Anal. Biochem. 209, 258-266. doi: 10.1006/abio.1993.1117

Gao, L., Zhuang, J., Nie, L., Zhang, J., Zhang, Y., Gu, N., et al. (2007). Intrinsic peroxidase-like activity of ferromagnetic nanoparticles. Nat. Nanotechnol. 2, 577-583. doi: 10.1038/nnano.2007.260

Guo, F. F., Yang, W., Jiang, W., Geng, S., Peng, T., and Li, J. L. (2012). Magnetosomes eliminate intracellular reactive oxygen species in Magnetospirillum gryphiswaldense MSR-1. Environ. Microbiol. 14, 1722-1729. doi: 10.1111/j.1462-2920.2012.02707.x

Heyen, U., and Schüler, D. (2003). Growth and magnetosome formation by microaerophilic Magnetospirillum strains in an oxygen-controlled fermentor. Appl. Microbiol. Biotechnol. 61, 536-544.

Imlay, J. A. (2003). Pathways of oxidative damage. Annu. Rev. Microbiol. 57, 395-418. doi: 10.1146/ annurev.micro.57.030502.090938

Jogler, C., and Schüler, D. (2009). Genomics, genetics, and cell biology of magnetosome formation. Annu. Rev. Microbiol.
63, 501-521. doi: 10.1146/ annurev.micro.62.081307.162908

Kasama, T., Pósfai, M., Chong, R. K. K., Finlayson, A. P., Buseck, P. R., Frankel, R. B., et al. (2006). Magnetic properties, microstructure, composition, and morphology of greigite nanocrystals in magnetotactic bacteria from electron holography and tomography. Am. Mineral. 91, 1216-1229. doi: 10.2138/am.2006.2227

Komeili, A. (2006). Magnetosomes are nized by the actin-Like protein MamK. Science 311, 242-245. doi:

Komeili, A. (2012). Molecular mechanisms of compartmentalization and biomineralization in magnetotactic bacteria. FEMS Microbiol. Rev. 36, 232-255. doi: 10.1111/j.15746976.2011.00315.x

Liu, J. N., Ding, Y., Jiang, W., Tian, J. S., Li, Y., and Li, L. J. (2008). A mutation upstream of an ATPase gene significantly increases magnetosome production in Magnetospirillum gryphiswaldense. Appl. Microbiol. Biotechnol. 81, 551-558. doi: 10.1007/s00253-0081665-1

Liu, Y., Li, G. R., Guo, F. F., Jiang, W., Li, Y., and Li, L. J. (2010). Large-scale production of magnetosomes by chemostat culture of Magnetospirillum gryphiswaldense at high cell density. Microb. Cell. Fact. 9, 99. doi: 10.1186/1475-2859-9-99

Matsunaga, T., Okamura, Y., and Tanaka, T. (2004). Biotechnological application of nano-scale engineered bacterial magnetic particles. J. Mater. Chem. 14, 2099-2105. doi: $10.1039 / \mathrm{b} 404844 \mathrm{j}$

Mitraki, A., Sonkaria, S., Fuentes, G., Verma, C., Narang, R., Khare, V., et al. (2012). Insight into the assembly properties and functional organisation of the magnetotactic bacterial actin-like homolog, MamK. PLoS ONE 7:e34189. doi: 10.1371/journal.pone.0034189

Nakamura, C., Kikuchi, T., Burgess, J. G., and Matsunaga, T. (1995). Ironregulated expression and membrane localization of the magA protein in Magnetospirillum sp. strain AMB-1. J. Biochem. 118, 23-27. cell membrane invaginations orga10.1126/science.1123231

maintaining for a little while, and then showing a little decrease. The overall trends of this preliminary data are the same with our formally addressed data.

FIGURE S2 | Statistical processing of the magnetosome number per cell at four sampling time points. Horizontal axis: The eight classes that magnetosome numbers per cell are grouped in. Vertical axis: Percentage of magnetosome number among the eight classes. Ave: average magnetosome number per cell. SD: standard deviation.

Perez, J. M., Arenas, F. A., Pradenas, G. A., Sandoval, J. M., and Vasquez, C. C. (2008). Escherichia col YqhD exhibits aldehyde reductase activity and protects from the harmful effect of lipid peroxidation-derived aldehydes. J. Biol. Chem. 283, 7346-7353. doi: 10.1074/jbc.M708846200

Pieterse, B., Leer, R. J., Schuren, F. H., and van der Werf, M. J. (2005). Unravelling the multiple effects of lactic acid stress on Lactobacillus plantarum by transcription profiling. Microbiology 151, 3881-3894. doi: $10.1099 /$ mic.0.28304-0

Pollithy, A., Romer, T., Lang, C., Muller, F. D., Helma, J., Leonhardt, H., et al. (2011). Magnetosome expression of functional camelid antibody fragments (nanobodies) in Magnetospirillum gryphiswaldense. Appl. Environ. Microbiol. 77, 6165-6171. doi: 10.1128/AEM.05282-11

Scheffel, A., Gruska, M., Faivre, D. Linaroudis, A., Plitzko, J. M., and Schüler, D. (2005). An acidic protein aligns magnetosomes along a filamentous structure in magnetotactic bacteria. Nature 440, 110-114. doi: 10.1038/nature04382

Schüler, D. (1999). Formation of magnetosomes in magnetotactic bacteria. J. Mol. Microbiol. Biotechnol. 1, 79-86.

Schüler, D., Uhl, R., and Bäuerlein, E. (1995). A simple light scattering method to assay magnetism in Magnetospirillum gryphiswaldense. FEMS Microbiol. Lett. 132, 139-145. doi: 10.1111/j.15746968.1995.tb07823.x

Schultheiss, D., Handrick, R., Jendrossek, D., Hanzlik, M., and Schüler, D. (2005). The presumptive magnetosome protein Mms16 Is a poly(3-Hydroxybutyrate) granule-bound protein (Phasin) in Magnetospirillum gryphiswaldense. J. Bacteriol. 187, 2416-2425. doi: 10.1128/JB.187.7.2416-2425.2005

Sun, J. B., Zhao, F., Tang, T., Jiang, W. Tian, J. S., Li, Y., et al. (2008). Highyield growth and magnetosome formation by Magnetospirillum gryphiswaldense MSR-1 in an oxygen-controlled fermentor supplied solely with air. Appl.
Microbiol. Biotechnol. 79, 389-397. doi: 10.1007/s00253-008-1453-y

Zhang, W. J., Chen, C. F., Li, Y., Song, T., and Wu, L. F. (2010). Configuration of redox gradient determines magnetotactic polarity of the marine bacteria MO-1. Environ. Microbiol. Rep. 2, 646-650. doi: 10.1111/j.1758-2229.2010.00150.x

Zhang, Y., Zhang, X., Jiang, W., Li, Y., and Li, J. (2011). Semicontinuous culture of Magnetospirillum gryphiswaldense MSR-1 cells in an autofermentor by nutrientbalanced and isosmotic feeding strategies. Appl. Environ. Microbiol. 77, 5851-5856. doi: 10.1128/AEM.05962-11

Zhu, K., Pan, H., Li, J., Zhang, K. Y., Zhang, S. D., Zhang, W. Y., et al. (2010). Isolation and characterization of a marine magnetotactic spirillum axenic culture $\mathrm{QH}-2$ from an intertidal zone of the China Sea. Res. Microbiol. 161, 276-283. doi: 10.1016/j.resmic 2010.02.003

Conflict of Interest Statement: The authors declare that the research was conducted in the absence of any commercial or financial relationships that could be construed as a potential conflict of interest.

Received: 20 April 2013; accepted: 07 July 2013; published online: 24 July 2013.

Citation: Yang J, Li S, Huang X, Tang T, Jiang W, Zhang T and Li Y (2013) A key time point for cell growth and magnetosome synthesis of Magnetospirillum gryphiswaldense based on real-time analysis of physiological factors. Front. Microbiol. 4:210. doi: 10.3389/fmicb. 2013.00210

This article was submitted to Frontiers in Aquatic Microbiology, a specialty of Frontiers in Microbiology.

Copyright (c) 2013 Yang, Li, Huang, Tang, Jiang, Zhang and Li. This is an open-access article distributed under the terms of the Creative Commons Attribution License, which permits use, distribution and reproduction in other forums, provided the original authors and source are credited and subject to any copyright notices concerning any thirdparty graphics etc. 